\title{
Kætteri som aksetids- og semiotisk fænomen ${ }^{1}$
}

\author{
ANDERS KLOSTERGAARD PETERSEN
}

Si vero altera harum ecclesiarum in alteram saeviendi habet potestatem, rogo quaenam ex duabus, et quo jure? Respondebitur sine dubio orthodoxa in errantem, vel haereticam. Hoc est magnis et speciosis verbis nihil dicere. Quaelibet ecclesia orthodoxa est, aliis erronea, vel haeretica; siquidem quae credit vera esse credit, quuae in diversum abeunt erroris damnat.

Locke, Epistola de Tolerantia. ${ }^{2}$

English abstract: In this explorative essay, I venture to raise the question of the origin of notions of heresy. Contrary to the dominating trajectory in current scholarship which claims that the category of heresy is a Christian construction dating to the time of the heresiologists, I argue that it should be conceived of as an axial age phenomenon closely connected to the transition from locative types of religion to utopian ones. I contend that the historical presuppositions for the latter Christian coinage of the category of

1 I kærlig erindring og dyb taknemmelighed tilegnet mindet om min nære ven, generøse og lærde kollega, Professor, Dr., Friedrich Avemarie, 19.10.1960-12.10.2012, som gav så meget til andre, og fik så kort et liv.

2 Her citeret efter Montuori-udgaven. Citatet lyder i oversættelse: “Men hvis en af disse kirker [den Armenske og den Reformerte, sic AKP] har magt til at rase mod den anden, spørger jeg hvilken og med hvilken ret? Der vil utvivlsomt svares den Ortodokse frem for den fejlagtige eller kætterske. Det er med store og besnærende ord at sige intet. For enhver kirke er i forhold til sig selv ortodoks, men for andre fejlagtig eller kættersk. Hvad enhver kirke tror, tror den at være sandt, og den forbander som fejl, hvad der adskiller sig i modsat retning." Oversættelsen her og de øvrige fra græsk, latin og fransk er, medmindre andet er anført, mine egne. I forbindelse med udarbejdelsen af artiklen er jeg min kollega, professor, dr. theol. Hans Jørgen Lundager, stor tak skyldig. Hans Jørgen Lundager har igen uegennyttigt kommet med mange forbedringsforslag og interessante overvejelser, som jeg har indarbejdet i det færdige essay. 
heresy should be found in the cultural and social nexus related to the emergence of axial age cultures. I point to the Graeco-Roman medical and philosophical traditions as the background for the later development of the specific category of heresy. Inspired by the work of Rebecca Lyman, I argue that it is historically and mereologically (the science concerning the relationship between parts and the whole) flawed to search for the origin of a comprehensive phenomenon in one religious current only. Particularly in the philosophical schools contemporaneous with the heresiologists, we find close resemblances to the Christian idea of heresy and orthodoxy. Ultimately, I argue that the concept of heresy defined as a third-order concept presupposes a context in which different currents made claims on the same discursive space with a simultaneous negation of rivaling trajectories as erroneous. I contend that orthodoxy emerges from an institutional and rhetorical positioning that closes the openness of the historical situation by semiotically freezing a particular configuration of signs (including social and ritual practice) and concomitantly segregating rivaling interpretations (including social and ritual practice).

DANSK RESUMÉ: Min artikel har en eksplorativ karakter. Den er et forsøg på at komme til klarhed over fænomenet kætteri. Frem for som $i$ den altdominerende strømning $i$ moderne forskningshistorie at gøre kætteri til en kristen opfindelse argumenterer jeg for at se det $i$ sammenhæng med aksetidsproblemstillingen og $i$ særdeleshed $i$ overgangen fra en lokativisk til en utopisk religionsform. Jeg hævder, at man kan finde paralleller $i$ de græsk-romerske medicinske og filosofiske skoledannelser. Afslutningsvis argumenterer jeg for forståelsen af kætteri som tredje-ordens-begreb, der forudsætter en kontekst, hoor forskellige, men beslægtede retninger inden for samme overordnede bevægelse gør krav på samme diskursive rum med en simultan afskrivning af rivaliserende strømninger som mangelfulde. Ortodoksi udspringer i den sammenhæng af en institutionel, retorisk positionering, som lukker den historiske situations åbenhed gennem semiotisk fastfrysning af en bestemt tegnfortolkning (inkl. social/rituel praksis) med tilsvarende udsondring af rivaliserende tegnfortolkninger (inkl. social/rituel praksis).

Keywords: Heresy; Orthodoxy; Heterodoxy; Axial Age; Utopian form of religion; Locative form of religion; Rebecca Lyman; Semiotics.

\section{Den aktuelle kætterforskning og dens tre typiske misvisninger}

Det er ofte blevet hævdet, at der består en snæver sammenhæng mellem kætteri og kristendom. Det, tror jeg, er rigtigt. Det giver god mening at argumentere for, at den måde, vi i dag italesætter kætteri som religionsfænomenologisk, sociologisk og historisk kategori, i vid udstrækning er en kristen frembringelse, som hører perioden fra 
midten af det andet århundrede og frem til. ${ }^{3}$ Justin og de senere såkaldte kristne hæresiologer (dvs. dem som skrev mod kætterne) som fx Irenæus, Tertullian, Hippolyt og Epifanios af Salamis er i den sammenhæng nøglepersoner, om end allerede Ignatius af Antiokia ved begyndelsen af det andet århundrede havde ansatser til denne udvikling, ligesom den også findes forudskikket i de sene nytestamentlige skrifter; men der består også en fare i at gøre kætteri til en eksklusiv kristen opfindelse. Derved risikerer man at overse de kultur- og socialhistoriske forudsætninger for den specifikt kristne kætterkategori, ligesom man lukker øjnene for de potentialer for komparative undersøgelser, som hører en ordentlig analyse af fænomenet til. Det er ganske vist rigtigt, som det er blevet fremhævet i moderne kætterforskning, at selve kætterkategorien og dens italesættelse er en kristen konstruktion; men verbaliseringen af et fænomen er ikke identisk med dets oprindelse. Man kan udmærket have eksistensen af et fænomen, som først på et senere tidspunkt gøres til genstand for metateoretisk refleksion og derigennem italesættes gennem anden- eller tredje-ordens-kategorier. Fænomenet religion fx har en lang virkningshistorie uafhængigt af dets verbale konceptualisering, og det vil være absurd at hævde, at kultur først opstod med italesættelsen af fænomenet. Det er afgørende, at man analytisk er i stand til at skelne mellem fænomen og begreb.

Det forekommer mig, at hovedstrømninger i den aktuelle forskning i kætteri, hvad enten den drives på overvejende historiske eller primært sociologiske vilkår, har en tendens til at begå tre grundlæggende analytiske fejltagelser, som jeg kort vil forholde mig til. For det første er man i den del af forskningen, som i særlig grad er optaget af kætterfænomenets fremkomst, tilbøjelig til at forveksle kætteri med hæresi. Det er rigtigt, at der i brugen af begrebet hairesis på græsk og det beslægtede latinske ord secta fandt en udvikling sted i århundrederne omkring vor tidsregnings begyndelse, som kulminerede med de kristne hæresiologers negative anvendelse af termen som betegnelse for kætteri; men det er som om, man har overset, at andre begreber i tidligere tid kunne bruges om beslægtede fænomener, ligesom man heller ikke i fornøden grad sondrer mellem fremkomsten af et fænomen og dets verbalisering. ${ }^{4}$ Sociale udstødelsesmekanismer findes også på tidligere historiske trin, uden at de nødvendigvis artikuleres sprogligt. Denne antagelse rejser imidlertid spørgsmålet om forholdet mellem almene, sociale udstødelsesmekanismer og kættergørelse. Dette spørgsmål er for omfattende til at kunne diskuteres i denne artikel.

3 Det er fx det bærende synspunkt hos Virginia Burrus, som i en afhandling, der har haft betragtelig indflydelse i moderne forskning, hævder: "The conceptual foundations of the categories of orthodoxy and heresy were laid during the second-century gnostic controversy in the polemical writings of Justin and Irenaeus" (Burrus 1995, 15).

4 Marcel Simon $(1979,111)$ har med rette fremdraget, at haresis måske ikke er det mest centrale udtryk, når man vil finde kætteriets historiske udspring: "If we look for possible pagan antecedents of the Christian notion of heresy, they are to be found in the history not of the term hairesis but of another term destined to play a remarkable role in the vocabulary of the Christian tradition - a word that will become a synonym for heresy: heterodoxy." 
For det andet er der i forskningen en tilbøjelighed til at sammenblande og forveksle en historisk og en sociologisk problemstilling, som jeg synes, man gør klogt i i højere grad at differentiere imellem. Skønt man i løbet af de sidste 30 år for alvor har taget til sig, at kætteri og brugen af kætterbetegnelsen er et diskursivt, semiotisk fænomen, er det, som om man undertiden fortrænger eller måske rettere tilsidesætter denne erkendelse i fremstillingen af, dels hvad kætteri er, dels hvordan det skal defineres. Når man som fx George Zito sociologisk argumenterer for, at et udsagn er "heretical insofar as it articulates, or threatens to expose, the contradictory dialectical meanings necessarily contained in any ideological thesis that has obtained a measure of institutional support and is therefore an orthodox way of speaking about the world" $(1983,129)$, har man fjernet historisk åbenhed fra problemstillingen og reificeret en bestemt parts forståelse og krav på ortodoksi. Eller sagt på anden vis og igen med reference til Zitos indflydelsesrige artikel: Når han definerer hæresi eller kætteri som det forhold, at "the speaker employs the same language as the parent group, retains its values, but attempts to order its discourse to some other end" (ibid., 125), har han ret, men alene fra et bagudskuende perspektiv. Problemet i hans og mange andres forståelse er, at en bestemt opfattelse essentialiseres som et udtryk for en ortodoksi i forhold til det efterfølgende hæresi som en afvigelse. ${ }^{5}$ Men det har, som vi skal se, netop været en hovedpointe i moderne hæresiforskning at gøre op med hæresiologernes kausalhistoriske og teologiske påstand om, at ortodoksi altid går forud for hæresi, og at kætteri derfor er et ufuldkomment derivat, hvis ikke ligefrem en pervertering af 'den oprindeligt rene og sande lære.' Det gælder her, som John Locke betonede i sin Epistola de Tolerantia fra 1689 , at i egen forståelse er enhver ortodoks. Det indebærer, at man ikke fra et historisk perspektiv uden videre kan fastfryse en bestemt forståelse som ortodoks og lade afvigende eller rivaliserende opfattelser gælde som heterodokse eller hæretiske - det kan kun lade sig gøre retrospektivt. I en lang række tilfælde, men ikke nødvendigvis alle, er det et åbent spørgsmål, hvem der i den historiske situation institutionelt får magten over betydningsdannelsen eller semiosis (jf. Petersen 2009a, 28-30; 2012, 155-60). Eksemplet Origenes kalder i den sammenhæng også på besindelse på kætterkategoriens socialt-relationelle karakter. Origenes blev i sin egen samtid og de efterfølgende århundreder i vide kredse opfattet som indbegreb af ortodoksi, mens en række af hans læresætninger i midten af det sjette århundrede af Det Femte Økumeniske Koncil og senere af Kejser Justinian blev fordømt som kætterske. Ikke desto mindre er der naturligvis den kerne af sandhed i opfattelsen, at man dårligt kan tænke begrebet hæresi uden en parallel forestilling om ortodoksi. De to begreber forudsætter hinanden. Det gælder her, hvad Gordon Leff med rette pointerer: "Heresy is defined in reference to orthodoxy. It does not exist alone. A doctrine, a sect or an individual becomes heretical when condemned as such by the church" $(1967,1)$.

5 Samme problem gør sig også gældende i Berlinerblaus i øvrigt meget læseværdige og tankevækkende artikel, når han hævder: "Put simply (and tautologically), heresy is something that an orthodoxy calls heresy" (2001, 332). 
For det tredje og forbundet med de to forudgående pointer gælder, at der i indflydelsesrige strømninger i nyere kætterforskning er en tendens til at sammenblande distinkte analytiske niveauer. Såfremt man lægger afgørende vægt på den begrebsterminologiske udvikling af det græske ord hairesis eller latin secta og gør det til nøgle for den religionsfænomenologiske, sociologiske og historiske forståelse af kætterfænomenet, har man sammenblandet et emic med et etic analyseniveau. Som allerede antydet, står og falder kætterfænomenet ikke nødvendigvis med de kristne hæresiologers særlige prægning af hairesis-begrebet. Det giver fx udmærket mening at tale om en rivalisering blandt beslægtede grupper om at repræsentere den sande overlevering af den autoritative tradition med en dertil knyttet afskrivning af de øvrige grupper som sande traditionsbærere inden for områderne græsk-romersk medicin og filosofi. Skønt der ikke her findes en institutionaliseret form for udstødelsesmekanisme eller en lige så klart profileret retorisk afvisning af konkurrerende grupper, som vi finder det hos de kristne hæresiologer, kan man dårligt afvise, at vi også her tekstuelt møder stigmatisering af rivaliserende anskuelser som falske traditionsbærere. Dertil kommer en i forhold til hæresiologerne beslægtet diskursiv kamp om nøglesymboler, som når man fx inden for betydningsfulde strømninger i græsk-romersk filosofi kæmpede om retten til Sokrates-figuren eller inden for græsk-romersk medicinsk litteratur om diskursivt patent på Hippokrates-skikkelsen. Daniel Boyarin (2004, 37-73) har tilsvarende argumenteret for, at Justins hæresi-begreb har en solid baggrund i jødedommen og således ikke er en specifikt kristen konstruktion. Der er dog et element, som gør det særligt oplagt at se på sammenhængen mellem kætteri og det, vi fra et moderne etic perspektiv betegner religion. Det drejer sig om forbindelsen mellem kætteri og ritualisering. Der er ingen tvivl om, at ritualet i forbindelse med religioner, som hører hjemme i en utopisk sammenhæng, ${ }^{6}$ får en særlig karakter. Jeg har i flere sammenhænge argumenteret for, at ritualet i den utopiske religionskontekst får karakter af en indeksikal markering af det doktrinære propositionelle indhold i religionerne. Det betyder ikke, at ritualet qua handling ændrer karakter, men den 'mytiske' ramme, som ritualet er indlejret i, får en ny prægning (jf. Petersen 2011, 15-20.34f.).

6 Utopisk religionsform er en kategori, som stammer fra religionsforskeren Jonathan Z. Smith. Han anvender den til at betegne de former for religion, som vokser frem i hellenistisk tid og som netop er karakteriseret ved, at de i modsætning til lokativiske religionsformer orienterer sig mod et sted uden for denne verden og ikke mod den lokale tempelinstitution, ligesom de lægger vægt på de religiøse udøveres tiltagende ligedannelse gennem livet med guden. Som sådan bryder utopiske religionsformer med den forestilling om ontologisk differens, der er karakteristisk for tempelinstitution og den lokativiske religionstype, som den er indfældet i, jf. Smith 1978, 132-40; 1990, 120f. For min egen udvidede brug af Smiths skelnen, se fx Petersen 2011; 2013a. 


\section{Kætteri i et nyt lys}

Dette essay har en eksplorativ karakter, for så vidt som jeg endnu ikke er kommet til klarhed i mine overvejelser over fænomenet. Ikke desto mindre vælger jeg at lægge dem frem, dels fordi jeg håber, at de kan være andre til inspiration, dels fordi jeg dermed forsøger at skrive mig selv til øget klarhed over et i religionsvidenskabelig sammenhæng betydningsfuldt fænomen (se mit tidligere essay om emnet, Petersen 2003). Dertil kommer, at artiklen gennem dets påpegning af en tæt forbindelse mellem kætteri og utopisk religion er ment som bidrag til det forskningsprojekt, vi i øjeblikket er ved at sætte i søen ved Religionsvidenskab ved Aarhus Universitet: En gennemskrivning af religionshistorien fra et kulturevolutionært perspektiv.

Min tanke er at se på kætterfænomenet fra et historisk, religionsfænomenologisk og semiotisk perspektiv. Jeg argumenterer med det meste af forskningen for, at hæresi som specifik kategori er en kristen frembringelse; men samtidig hævder jeg, at kætteri er del af et bredere historisk og socialt fænomen, hvis forudsætninger man skal finde i overgangen fra arkaiske til historiske religioner eller i bevægelsen fra lokativiske til utopiske religionstyper. Kætteri kan dårligt tænkes uafhængigt af fremvæksten af skriftkulturer. ${ }^{7}$ Det er den skriftlige fiksering af traditionen, som overhovedet gør det muligt at etablere en fælles målestok for henholdsvis ideal adfærd og idealt doktrinært indhold inden for gruppen. I det øjeblik en fælles autoritativ tradition lader sig fiksere, kan ændringer i forhold til den i en bestemt situation autoritative udlægning af traditionen potentielt stigmatiseres som kætteri. Dertil kommer, at utopiske religionsformer med nidkær insisteren på egen traditions eksklusive sandhed er mere tilbøjelige til at geråde i kamp med alternative verdenssyns parallelle krav på at repræsentere den virkelige virkelighed end lokativiske religionstyper, som uproblematisk kan leve med andre steders guddommelige nærvær.

Yderligere forfægter jeg det synspunkt, at kætterkategorien og italesættelsen af kætteri er element $i$ et betydeligt bredere semiotisk fænomen, som har med kontrol og censur af tegnprocesser at gøre. Det er fx velkendt, hvordan kætterkategorien i moderne tid har nydt udbredelse i en politisk institutionel kontekst, ikke mindst i kommunistiske eller marxistiske regimers jagt på forrædere mod den sande forståelse af den autoritative overlevering. Det er netop forståelsen af kætteri som bredere historisk, socialt og semiotisk fænomen, jeg i dette essay ønsker at fremhæve. Endelig argumenterer jeg for en snæver sammenhæng mellem italesættelsen af kætteri og andre former for othering som fx hekseri, trolddom og magi, ikke mindst når det gælder adfærds- og dermed også ritualniveauet. Kætteri er blot en blandt andre strategier for othering, gennem hvilken man konstruerer gruppens identitet (Arnal 2008, 53f.); men kætteri

7 Jeg deler her Berlinerblaus anliggende (2001, 333f.), som også over for en række sociologiske arbejder fremhæver kætterfænomenets universelle karakter og er interesseret i dels de socialhistoriske betingelser for kætterfænomenets fremvækst, dels de fortsatte kultur- og socialhistoriske forudsætninger for fænomenets tilstedeværelse. 
udgør også en særlig form, fordi den drejer sig om othering i gruppen selv (Petersen 2012b). Det er her ikke den fremmede uden for gruppen, men i stedet den fremmede i gruppen selv, i hvis modbillede man skaber egen identitet. Det gælder her, som det hedder i Den Romersk-Katolske Kirkes officielle definition af kætteri:

Incredulitas est veritatis revelatae negligentia vel voluntaria recusatio illi assensum praebendi. «Dicitur haeresis, pertinax, post receptum Baptismum, alicuius veritatis fide divina et catholica credendae denegatio, aut de eadem pertinax dubitatio; apostasia, fidei christianae ex toto repudiatio; schisma, subiectionis Summo Pontifici aut communionis cum Ecclesiae membris eidem subditis detrectatio»." (med henvisning til CIC, can. 751). ${ }^{8}$

Kætteri drejer sig med andre ord om forræderen i gruppen selv. Det er han eller hende, som trods rituel indlemmelse i gruppen stædigt fastholder afvigende synspunkter, som er kontrære mod centrale doktriner i gruppens verdenssyn. Det betyder også, at kætteri er knyttet til gruppedynamik og gruppebeskyttelse. Stigmatisering af kættere er en blandt andre måder, grupper beskytter sig mod dissens eller forræderi ved at udskille de elementer, som i tanke, tale og/eller handling truer gruppens identitet; men igen skal man passe på terminologien. For hvem er det, som definerer en bestemt gruppes identitet, hvad enten det gælder tanke eller handling?

Man skal som allerede understreget være forsigtig med ikke at tilbageprojicere senere tiders ortodoksi til perioder, hvor den historiske situation var principielt åben over for, hvilken tegnbrug der i sidste instans endte med at indholdsbestemme den semiosis, der for eftertiden blev den institutionelt dominerende. Eller sagt på anden vis og formuleret i mindre abstrakt sprogbrug: Der var i slutningen af det andet og begyndelsen af det tredje århundrede e.v.t. intet, som med nødvendighed indebar, at hæresiologernes også indbyrdes forskellige opfattelse(r) kom til at fremstå som indbegreb af ortodoksi. Når talen falder på ortodoksi og hæresi, har vi en tilbøjelighed til at glemme, at vi står over for sproglige konstruktioner og ikke faktuelle forhold, dvs. forsøg på ideologisk at ændre verden, men ikke billeder af verden selv (Jf. King 2008, 28). Det lader vi os let hilde af, så vi fx tager Irenæus' selvforståelse for pålydende. Det gælder her, som det fx er blevet pointeret af Boudewijn Dehandschutter $(2011,14)$ :

The concern to explain continuity blinds Irenaeus to the pluriform character of the apostolic tradition, not to mention its contradictory aspects. He could not imagine that one

8 Katekismen tredje del, om livet i Kristus, sektion to, om de ti bud, kapitel et "Du skal elske Herren din Gud af hele dit hjerte og med hele din sjæl og med hele dit sind", artikel et Det Første Bud "Du skal tilbede Herren din Gud og ham alene skal du tjene", § 2089. På dansk: "Vantro vil sige at afvise den åbenbarede sandhed eller den bevidste afvisning af tilslutningen til den. Hæresi vil sige efter dåben dumstædigt at benægte sandheden, som skal tros med guddommelig og almen tro, eller den er tilsvarende en obsternasig tvivl om samme. Frafald er den totale afvisning af den kristne tro. Skisma vil sige afvisningen af underkastelse under Paven eller det fællesskab med Kirkens medlemmer, som er underkastet ham." 
apostolic tradition could be in conflict with another, and that this provokes tensions which are not automatically neutralized by a notion of canon.

I det hele taget skal man vogte sig for at anvende et begreb som ortodoksi i en situation, hvor det semiotiske spil om kampen til at definere sand fortolkning endnu var åben; men omvendt peger Den Romersk-Katolske Kirkes definition af kætteri i Katekismen på et forhold, som vi er nødt til at medtænke. Det drejer sig om institutionaliseringens betydning for forståelsen af kætteri. Fra det øjeblik hvor man har en stærk institution som garant for en bestemt type af fortolkninger (der er, vil jeg godt understrege, aldrig én, men som minimum en konfiguration af bestemte fortolkninger med en så tilpas grad af beslægtethed, at det er meningsfuldt at tale om dem som en fortolkningskrystallisering), er mulighederne for at afvise konkurrerende fortolkninger også betragtelig øget; men på ny skal man være forsigtig, at man ikke alt for let kommer til at overtage og bekræfte en mytisk forestilling om indre kontinuitet og konsistens, som ikke har eksisteret historisk. Ortodoksi er egentlig et resultat af en prioritering og udkrystallisering af bestemte tegnkonfigurationer, uden at disse tegnkonfigurationer nødvendigvis fortolkes identisk over tid og rum, endsige at ortodoksien trods en i udgangspunktet institutionel rygdækning faktisk lader sig gennemføre. Det er antagelig den manglende 'ortodoksi' i den konkrete sociale og kulturelle situation, som fremtvinger det retorisk-ideologiske behov for ikke alene at verbalisere men også at fremtvinge en ortodoksi, skønt forsøget er dømt til at mislykkes som andet og mere end en semiotisk prioritering.

Uden tvivl bør den institutionelle dimension medtænkes i forståelsen af kætteri; men hvordan det kan gøres, er ikke ganske klart. Skønt det måske nok er fristende at hævde, at den historiske åbenhed er væk i det øjeblik, en stærk institution kan garantere fastholdelsen af en ortodoksi, kommer denne forståelse i vanskeligheder, når man står over for mere komplicerede situationer som fx reformationsbevægelserne i det 16 . århundrede. Her formåede ortodoksien trods institutionel opbakning ikke at sætte sig igennem. Og igen skal man være forsigtig, for selve tanken om 'mere komplicerede historiske situationer' kan være mindre afklarende, end den lader forstå; for kan man meningsfuldt hævde, at der findes historiske situationer, som hverken kulturelt eller socialt skulle være komplicerede? Det er også et åbent spørgsmål, i hvilken udstrækning sammenhængen mellem øget institutionalisering og muligheden for gennemførelse af ortodoksi gælder i forhold til kristendom i tiden efter Konstantin d. Store og Theodosios d. Første, hvor en bestemt type af kristendomsfortolkninger fik en særlig institutionel gennemslagskraft. Her er man nødt til at spørge, om ikke påstanden om ortodoksi altid i højere grad er et udtryk for en ideologisk besværgelse end for en spejling af den sociale virkelighed. Under alle omstændigheder opfatter jeg det som væsentligt over for betydelige dele af forskningen at fastholde denne åbenhed i andre og også ikkereligiøse sammenhænge, hvor kætterkategorien er relevant.

En passant vil jeg godt nævne et tankevækkende eksempel, som Einar Thomassen har fremdraget i en artikel om kætteri, What Is Heresy, and Why Did It Matter?. Thomas- 
sen henviser her til en undersøgelse af Sylvia Fuller om kontroverser inden for amerikansk bjergklatring, hvor man i 1980'erne havde voldsomme diskussioner inden for klatrersamfundet afstedkommet af nye, lettere og mere sikre klatreteknikker som 'hangdogging' og 'rap bolting'. Det førte til en kamp mellem traditionalister og dem, traditionalisterne betegnede som 'tricksters', nemlig den gruppe, som gennem brug af nye teknikker i deres øjne forrådte selve den grundlæggende idé i bjergklatring. For traditionalisterne var der tale om et så fundamentalt eksistentielt ærinde, at der blev rapporteret flere sager om sabotage og vold. Fuller bruger i sin drøftelse af dette noget kuriøse eksempel begreberne ortodoksi og hæresi, hvilket får Thomassen til at konkludere:

\footnotetext{
Apparently some climbers had invested so much of their selfhood in climbing that they felt existentially threatened when new techniques were introduced that would, as they saw it, contaminate the purity of the 'style' and 'ethics' of traditional climbing. Such reactions can undoubtedly be found wherever people feel strongly enough about something that defines their identity and fills their life with meaning $(2012,197)$.
}

Tilsvarende eksempler kan fremdrages inden for området fan fiction, hvor det er karakteristisk, hvordan fans - helt parallelt med tilblivelsen af den tidlige kristne evangelielitteratur og apostelakter - skriver videre på de 'kanoniske' skrifter ved at udfylde lakuner og narrative mangler i de autoritative forlæg. Interessant i denne sammenhæng er det forhold, at der i relation til Star Wars-verdenen meget hurtigt er opstået spaltninger blandt tilhængerne og dannelsen af konkurrerende grupper kendetegnet ved hver deres 'kanoniske' regler for legitim videreskrivning. Det gælder særligt de grupper, som har valgt at ekstrapolere Star Wars fra den tekstuelle til den kulturelle og sociale verden, idet de på forskellig vis gør gældende, at 'the great power' beskrevet i Star Wars repræsenterer den sande guddom (Davidsen 2010). Der pågår på internettet i disse år en undertiden drabelig kamp mellem disse forskellige grupper, som ikke skyer religiøse diskursers voldsomme retorik i stigmatiseringen af rivaliserende grupper som frafaldne eller hæretikere i forhold til den 'ortodokse' viderefortolkning eller videreskrivning, som de opfatter sig som legitime garanter for og bærere af. Eksemplerne understreger ikke kun, hvordan kætterfænomenet ikke kan indskrænkes til et religiøst fænomen, men peger også på den historiske åbenhed for fortolkninger af et fælles accepteret grundlag.

\section{Den moderne kætterdiskussion}

Med disse lidt specielle eksempler in mente vender jeg mig mod den nyere forskningshistorie. Jeg vil fremhæve to bøger, som har været afgørende for den aktuelle drøftelse af hæresifænomenets historiske oprindelse. Jeg tager udgangspunkt i det værk, som om noget kan beskrives som forudsætning for de sidste 30 års diskussion af kætteri og 
kættere, nemlig Walter Bauers Rechtgläubigkeit und Ketzerei im ältestesten Christentum fra 1934..$^{9}$ Skønt bogen udkom for snart 80 år siden, skal man frem til den engelske oversættelse fra 1971, før bogen for alvor fik indflydelse på international forskning. Bogen var i sin samtid stærkt kontroversiel, og den er da også siden blevet kritiseret på en lang række punkter, men det ændrer ikke ved, at den på et afgørende punkt har præget hele den efterfølgende forskning. Skønt man nok kan kritisere Bauer selv for ikke i tilstrækkelig grad at løsrive sig fra ortodoksi-kætteri-distinktionen (jf. Boulluec 1985, 19), gjorde Bauer det en gang for alle klart, at der ikke eksisterer en naturlov, som tilsiger, at ortodoksi går forud for hæresi. Bauer viste, hvordan forskellige former for kristendom i Syrien, Lilleasien og Ægypten, som siden dømtes kætterske, i deres egen historiske kontekst udgjorde legitime former for kristendom, som kunne være blevet til ortodokse versioner af kristendommen. Omvendt gjaldt det, at de former, som man i dag opfatter som forudsætningerne for den senere ortodoksi, kunne være blevet erklæret for kætterske. Bauer kan fx om den ægyptiske udvikling hævde: “So ist also bis ins 3. Jahrhundert hinein keine Scheidung zwischen Rechtsgläubigkeit und Ketzertum durchgeführt, haben sich die Typen ganz und gar noch nicht deutlich gegeneinander abgegrenzt. Und bis tief ins 2. Jahrhundert ist das Christentum hier ausgesprochen unorthodox" $(1934,63)$. Det er nok at sætte Bauer på spidsen at spænde ham for det socialt-relationelle synspunkt, der lyder, at: "Min ortodoksi er din hæresi, og din ortodoksi mit kætteri"; men det er, skønt Bauer ikke selv drog de fulde konsekvenser af synspunktet, indeholdt $i$ hans argumentation.

Ifølge Bauer var fremvæksten af ortodoksi et fænomen, der i særlig grad var knyttet til en bestemt form for kristendom i Rom, som Bauer selv forstod som kontinuerlig fortsættelse af den tidligste Jesusbevægelse. Det var denne særlige romerske ortodoksi, som gjorde det muligt for kristendom at blive til verdensreligion: "Es ist ja ein merkwürdiges Spiel der Geschichte, daß das abendländische Rom dazu ausersehen war, gleich zu Beginn den bestimmenden Einfluß auf eine Religion, deren Wiege im Orient gestanden, auszuüben, um ihr diejenige Gestalt zu geben, in der sie Weltgeltung gewinnen sollte" $(1934,242)$. Omend måske nok noget ufrivilligt kom Bauer ikke desto mindre til at bane vej for en forskningstradition, som har gjort en afgørende - og efter min opfattelse korrekt - pointe ud af at betone kætteriets kontingente og socialt-relationelle karakter.

Denne forståelse er siden blevet betragteligt udviklet i Alain Le Boulluecs Foucaultinspirerede mesterværk, La notion d'hérésie dans la litterature grecque II ${ }^{e}-I I I^{e}$ siècles fra 1985, i hvilken ikke mindst det synspunkt er gjort gældende, at kætteri og ortodoksi er kristne opfindelser, som i særlig grad går tilbage til Justin. Le Boulluec har også en gang for alle slået fast, at kætter og ortodoks ikke er størrelser i virkeligheden, men centrale elementer i bestemte religiøse diskurser, gennem hvilke man konstruerer og

9 Der findes en udmærket diskussion af Bauer i Harrington 1980, og i særdeleshed i et delvist temanummer om bogen i JECS 14 (1996), som ud over et læseværdig forord af Lewis Ayres 2006, 395-98, har en oversættelse af en af de første anmeldelser af bogen, se Völker 2006. 
cementerer forskellige måder at skabe virkelighed og identitet gennem. Derfor vælger Boulluec også ganske sigende at bruge udtrykket: représentations hérésiologiques. Besværgende skriver han, at han først og fremmest er optaget af teksternes hæresiologiske repræsentationer for ikke at blive indfanget af hæresiologernes digitale måde at inddele verden: enten ortodoks eller heterodoks:

\footnotetext{
En choisissant de parles de »représentations hérésiologiques «, nous essayons de sortir du cercle des judgements de valeur impliqués par le terme »hérésie« et de l'abstraction de l'antithèse entre »hétérodoxie« et »orthodoxie«. À reprendre ces concepts, on risque de ne pouvoir se défaire des condamnations et des louanges qu'ils portent et de rester prisonnier des artifices hérésiologie $(1985,19){ }^{10}$
}

Her forlader jeg forskningshistorien, idet jeg fremhæver de tre pointer, som i forlængelse af Bauer og ikke mindst Le Boulluec har fået karakter af opinio communis i moderne forskning i kætterfænomenets fremkomst: For det første, at der er tale om et diskursivt, socialt-relationelt fænomen; for det andet, at ortodoksi, når det gælder den historiske fremkomst af hæresibegrebet, ikke går forud for hæresi; for det tredje, at hæresi-kategorien i særlig grad er en kristen konstruktion, hvis egentlige prægning skyldes Justin og de senere egentlige hæresiologer.

\section{De kristne hæresiologers prægning af hæresibegrebet}

Mens hairesis i århundrederne før vor tidsregnings begyndelse kunne betegne en skoledannelse i betydningen et bestemt sæt af forestillinger, som en given person kunne vælge (grundbetydningen af haireomai), refererede det ikke til en social institution (detaljeret diskussion i Glucker 1978, 166-92). Det kom det imidlertid i stigende grad til eller rettere, det blev stadig vanskeligere at skelne de to ting fra hinanden: hairesis som betegnelse for en åndsretning og som udtryk for en social institution. Når fx Josefus i Vita taler om, hvordan der var tre jødiske skoler (haireseis), betyder det slet og ret tankestrømninger: “Da jeg var næsten 16 år gammel, ønskede jeg fortrolighed med skolerne (tōn haireseōn empeiran) iblandt os. Der er tre af dem. Først farisæernes hairesis, dernæst saddukæernes hairesis, og for det tredje essæernes... I mit nittende år begyndte jeg at følge farisæernes hairesis, som minder om den hairesis blandt grækerne, som kaldes stoisk" (Vita 10). I Bellum opererer Josefus med en tilsvarende tredeling; men her er vægten i nogen grad flyttet over på hairesis som ikke alene åndsretning, men også som social institution: "Der findes nemlig hos jøderne tre filosofiske retninger;

"Ved at vælge at tale om hæresiologiske repræsentationer forsøger vi at bevæge os væk fra den cirkel af værdidomme, som er indeholdt i begrebet 'hæresi' og i det abstrakte modsætningspar 'heterodoksi' og 'ortodoksi'. Ved at tage disse begreber risikerer man ikke at kunne gøre sig fri af forbandelserne og lovtalerne, som bærer og forbliver det hæresiologiske kunstgrebs fange." 
tilhængerne (hairetistai) af den første hedder farisæerne, af den anden saddukæerne, og den tredje retnings tilhængere essæerne" (Bellum 2.119, jf. Ant. 18.11-22). Vi kan her se bort fra, at Josefus i Ant. taler om fire retninger (Ant. 18.23-25).

Tilsvarende kan Cicero i et brev til Cassius 125 år før Josefus' Bellum klandre Cassius for at have skiftet tilhørsforhold fra en filosofisk retning til en anden: "Jeg prøver dig nemlig nu for at se, i hvilken ånd du modtager det. For hvis du nemmer det tungt og besværligt, har jeg flere ting at sige og vil kræve, at du genindtræder i den skoleretning, fra hvilken du med kraft og med bevæbnede mænd blev udstødt (ex qua hairesei vi hominibus armatis deiectus sis)" (Epp. fam.15.16.3). Cicero lægger i brevet ikke skjul på sin forargelse over Cassius, som ifølge Cicero har sendt skilsmissebrev til dyden for i stedet at lade sig forhekse af vellyst, dvs. at Cassius har bevæget sig fra enten platonisme eller stoicisme til epikuræisme. Cicero stiller retorisk spørgsmålet: “Og hvem taler jeg med? Med en fri mand af stærkeste kaliber, som, siden han betrådte Forum første gang, intet har gjort, som ikke er af den mest udsøgte og ophøjede værdighed. I selve denne retning (hairesei), frygter jeg, er der ikke anden kraft, end jeg mener, at du finder det" (ibid.). Denne forståelse af hairesis som betegnelse for en bestemt tankeretning og nogle gange med en dertil hørende social institution levede videre hos senere kristne forfattere som fx Clemens af Alexandria og Origenes; men samtidig skete der fra og med Ignatius og tilspidset hos Justin en forandring af begrebet (parentetisk bemærket kan man iagttage samme sproghistoriske udvikling i det latinske begreb secta). Det kom som vort moderne kætterbegreb til at betegne afvigeren eller den udstødte, den som forbrød sig mod gruppens grundlæggende overbevisninger og/eller adfærd. Det tidligste klare eksempel på denne udvikling er Ignatius af Antiokia, som i sit Brev til Trallerne i 6, 1 skriver: “Jeg formaner jer - dog ikke jeg, men kærligheden, som hører Jesus Kristus til - om at I kun nyder den kristne føde, og at I holder Jer bort fra den fremmede plante, som er kætteri (hairesis)." Her er hairesis parallelt med det sene nytestamentlige skrift 2 Pet 2,1 - anvendt negativt om en åndsretning, man skal afstå fra at have noget at gøre med (jf. Titus 3,10). Det er her, vi finder kimen til det kristne hairesis-begreb, som får en endnu mere prægnant form fra Justin og frem.

I sin Første Apologi kap. 26 henviser Justin til et tidligere skrift, i hvilket han har opregnet samtlige forskellige haireseis, nu forstået som kætterier fra den sande forståelse af kristendom, som Justin i egen opfattelse repræsenterer. Om disse personer gælder, at de er særligt farlige for Justins kristendom, fordi de ifølge Justin kaldes kristne og derfor truer med at kontaminere begrebet. Det er dog ikke anderledes, hævder Justin, end hvad man finder inden for filosofien, hvor nogle også kalder sig filosoffer, skønt de ikke er det. Det sidste eksempel, jeg vil fremdrage, er fra Tertullians De praescriptione hereticorum, hvor man møder den kristne kætterkategori for fuld udblæsning. Kætteri bliver her slet og ret identificeret med ens selvvalgte afvigelse fra traditionen. I en henvisning i kap. 6 til Gal 5,20 hedder det: 
Men også i næsten ethvert brev, hvor han (sc. Paulus) indskærper os at fly falske læresætninger (adulterinis doctrinis fugiendis) dadler han kætterier (haereses), hvis gerninger er falske læresætninger: kætterier betegner på græsk det valg, hvorved enhver i højeste grad anvender dem til enten at belære eller at tilegne sig. Derfor betegnede han kætteren som selvfordømt, fordi han selv har valgt det, hvorved han fordømmes. Men for os er det ikke tilladt at indføre noget af egen mening (ex nostro arbitrio), ej heller at tilvælge noget, som en anden af egen mening har indført (De praesc. haer. VI, 2f. $)^{11}$.

Her har det kristne kætterbegreb nået sit klimaks. Kætteri er selvvalgt afvigelse og fravigelse fra traditionen. Men kætteriet her er set fra et bestemt perspektiv, hvis repræsentanter forsøger at sætte sig på det samlede diskursive rum. De, der her skrives ud af fællesskabet, er i egen forståelse selv ortodokse. Ser man imidlertid på den sproghistoriske udvikling for både hairesis og secta, er det rigtig, hvad John Glucker har fremhævet for begge begrebers grundbetydning, nemlig at vægten frem til de kristne hæresiologers overtagelse af de semantiske felter primært ligger på en abstrakt forståelse af henholdsvis hairesis og secta som 'overbevisning', 'positiv tilbøjelighed i retning af', 'tankestrømning', 'åndsretning', etc., men netop ikke skole i betydningen social institution (Glucker 1978, 173f., 187, 192, 205f.). Det er derfor også betydningsfuldt, at fx Jeronimus i den latinske oversættelse af Det Nye Testamente de steder, hvor hairesis for ham fremstår i betydningen 'sekt', vælger at oversætte det med latin heresis eller hairesis; mens han derimod oversætter hairesis i betydningen skoleretning, latin secta (Glucker 1978, 205).

\section{Kætteri i medicin og filosofi}

I lyset af denne meget kursoriske gennemgang af kætterbegrebets forskningshistorie og sproghistoriske udvikling vender jeg tilbage til det indledende spørgsmål om kætteri som aksetids- og semiotisk fænomen. Ud fra det foregående kunne man få det klare indtryk, som bekræftes af stort set al nyere forskning inden for området, at kætterkategorien er en kristen konstruktion. Alligevel er jeg tøvende. Der findes inden for både den græsk-romerske medicinske tradition og inden for den filosofiske tradition fænomener, der utvivlsomt hører med til den senere kætterkategoris historiske forudsætninger. Dertil kommer et forhold, som jeg vender mig mod i det efterfølgende afsnit. Kristendom var ikke på nogen måde en monolitisk størrelse i den kultur, den voksede frem i. Den var del af en større kulturel og social sammenhæng, og det ville være mærkeligt at forestille sig, at der ikke i beslægtede strømninger skulle kunne findes parallelle fænomener. Lad os dog for en stund lade det ligge og i stedet for vende os mod kætterfænomenets historiske forudsætninger i den medicinske og filosofiske tradition.

11 Oversat efter Corpus Christianorum-udgaven. 
Det er næppe tilfældigt, at allerede Origenes kunne henvise til både den medicinske og filosofiske tradition som forklaring på, at der også blandt kristne fandtes kætterier, ligesom vi har set, hvordan Justin i Den Første Apologi kan drage en parallel mellem kristne kætterier og splittelser blandt filosoffer. Origenes hævder i Contra Celsum, at det for en lære gælder, at dersom den har en alvorlig oprindelse og er gavnlig for menneskeheden, vil den også medføre kætterier. Som eksempel anfører han den medicinske tradition, der både er nyttig og nødvendig for menneskeheden, men som ikke desto mindre, når det gælder synet på, hvorledes man skal helbrede legemet, geråder i indre stridigheder. Det gælder både blandt grækere og barbarer (Contra Celsum III 12; jf. II 27 og V 61). Samme forhold gør sig gældende inden for filosofien, hvor Sokrates ifølge Origenes er blevet ophav til en lang række forskellige skoler (III 13, jf. III 12; V 61). Her ser vi først på den medicinske tradition.

Inden for den græsk-romerske medicinske tradition eksisterede den såkaldte hairesis-litteratur, som drøftede de forskellige medicinske skoledannelser positivt og negativt. Om denne litteratur, der til tider var ganske polemisk, når den var rettet mod medicinske retninger, man ikke selv tilhørte, skriver Heinrich von Staden:

Rather, the agōn with outsiders now is often, though by no means always, depersonalized at least superficially to the extent that polemics are ad sectam, not ad hominem, and the apologetics likewise pro secta sua. Certain individuals, to be sure, remain villains or heroes, but they are now presented - or present themselves - as members of a larger group (1982, 79).

Her finder vi faktisk noget, som ligner det senere kristne kætterfænomen i den forstand, at der også her er tale om en historisk åben situation, hvor forskellige grupperinger og retninger kæmpede mod hinanden om at repræsentere den sande form for hippokratisk medicin og hvor der finder en parallel retorisk afvisning af rivaliserende strømninger sted. Det er derfor heller ikke tilfældigt, at von Staden argumenterer for, at "Greek medicine is the more significant early nuturing ground for hairesis as a doctrinal group designation" (ibid., 81). Hvad vi til gengæld ikke finder i den græsk-romerske medicinske tradition, er den mere specifikke form for kætteri, der forudsætter en egentlig institutionel udsondring af de andre som hæretikere.

Samme forhold gør sig gældende i den græsk-romerske filosofiske tradition, men med den forskel, at man ikke her som inden for den medicinske tradition har en egentlig hairesis-litteratur. Ikke desto mindre finder man også i de hellenistiske filosofiske skoledannelser forskellige retninger, som rivaliserede med hinanden om at repræsentere den sandeste form for filosofi. Parallellen til det senere kristent prægede kætterfænomen er igen selve den historisk åbne situation, hvor konkurrerende strømninger kæmpede om retten til samme diskursive rum. De opfattedes som om ikke falske, så i alle tilfælde stærkt mangelfulde former for filosofi. Som i eksemplet med den medicinske tradition gælder her, at der hverken er tale om en decideret negativ brug af hairesis-begrebet selv eller en institutionaliseret form for udstødelsesmekanisme; men 
det ændrer ikke ved, at vi finder en slående parallel og religionshistorisk forudsætning for det senere kætterfænomen: forskellige retninger, der gør krav på samme diskursive rum med en tilsvarende afskrivning af rivaliserende strømninger som mangelfulde, fejlagtige og ufuldkomne. I den sammenhæng kan man hævde, at ortodoksi udspringer af en institutionel, retorisk positionering, som lukker den historiske situations åbenhed gennem semiotisk fastfrysning af en bestemt tegnkonfiguration (inkl. social/ rituel praksis) med en tilsvarende udsondring af rivaliserende tegnfortolkninger (inkl. social/rituel praksis).

\section{Kætteri og aksetid}

Det er ikke tilfældigt, at det senere kristent prægede kætterfænomen har sine forudsætninger her. Kætterkategorien forudsætter en skriftkultur med en skriftligt fikseret tradition, som forskellige fortolkninger kan måles og vejes i forhold til. Den forudsætter formentlig også skiftet fra lokativiske til utopiske religionsformer, fordi de sidste - og antagelig mest udtalt i de profilerede monoteistiske religioner - ikke kan leve med eksistensen af rivaliserende og alternative verdenssyn, heller ikke internt. Dertil kommer, at kætterkategorien også indebærer en social kontekst præget af stærk konkurrence mellem forskellige retninger, som alle gør krav på samme diskursive rum.

Alt dette er netop, hvad der er blevet fremhævet af en række forskere som kendetegnende for den overgang, man i forlængelse af Alfred Weber og Karl Jaspers ofte betegner aksetid (se hertil Bellah 2005 og 2011, 265-567). Jeg er ikke selv udelt begejstret for begrebet, som har nogle problematiske ideologiske konnotationer knyttet til sig, ligesom det ahistorisk lader antyde et særligt punktnedslag væsensforskelligt fra andre tidligere eller senere i historien. Selv foretrækker jeg i forhold til det specifikt religiøse område kategorien utopisk religion velvidende, at religion og kultur i den antikke verden med kun gradvise forskelle er stort set sammenfaldende størrelser (se Petersen 2012c, 13-15). På samme måde ville jeg foretrække et andet begreb for aksetid, men i denne sammenhæng lader jeg det stå, fordi dets hævdvundne referenceområde netop er, hvad jeg har i tankerne.

Som afslutning på dette essay vil jeg imidlertid, som allerede antydet, kort opholde mig ved temaet filosofi og religion i den kulturelle og sociale sammenhæng, som tidlig kristendom blev til i. Hvis det er rigtigt, hvad jeg i det forudgående har argumenteret for, at de historiske forudsætninger for kætterbegrebets fremkomst skal findes i aksetidskonteksten snarere end at forstås som en specifik kristen frembringelse, må der i den kultur- og socialhistoriske sammenhæng, som tidlig kristendom var del af, kunne peges på parallelle fænomener. Jeg skal ikke lægge skjul på, at der for mig er mere på spil end blot et spørgsmål om, hvorvidt kætterkategorien er en kristen konstruktion 
eller ej. For det første er der en væsentlig og mere grundlæggende kulturteoretisk, mereologisk drøftelse. ${ }^{12}$ I den historiske sammenhæng, som jeg her er optaget af, drejer den sig om, hvordan man skal tænke forholdet dels mellem del og helhed, dels mellem enkeltdele inden for helheden, in casu tidlig kristendom i forhold til den øvrige mediterrane verden og dertil relationen mellem tidlig kristendom og fx henholdsvis palæstinensiske og diasporaformer for jødedom. Denne problemstilling repræsenterer et genkommende kultur- og religionshistorisk problem: Hvordan skal man koncipere forholdet mellem forskellige kulturelle eller religiøse størrelser, som hører hjemme i samme tid og samme rum? For det andet er der en vigtig religionshistorisk diskussion, som angår konceptualiseringen af relationen mellem tidlig kristendom og dens historiske forudsætninger. Som mange vil vide, ligger der her en lang debat præget også af stærke ideologiske interesser: Blev tidlig kristendom til som brud med jødedom under påvirkning af den græsk-romerske verden, eller skal formativ kristendom snarere tænkes i kontinuitet med den jødiske verden uden nævneværdig påvirkning fra den græsk-romerske kultur- og religionssfære? Og igen kan man indsnævre spørgsmålet til en diskussion om, hvilke størrelser og strømninger inden for henholdsvis den græskromerske og den jødiske verden, tidlig kristendom blev til under påvirkning af.

Jeg har i en række år argumenteret for, at tidlig kristendom og dermed også jødedom, som den tidlige kristendom i et par hundreder af år var uadskillelig del af, hverken skal forstås som monolitiske eller isolerede størrelser i den antikke middelhavsverden (Petersen 2012c). De var del af en større kulturel og social koinē, som jeg i forlængelse af Martin Hengel vælger at lade hellenismefænomenet udgøre. Det betyder, at jeg forstår kategoriens referencefelt som et third- og ikke et second-orderfænomen, som blot skulle betegne den græske (og eventuelt romerske, afhængig af, hvor generøs man er i sine dateringer) verdens indflydelse på det større mediterrane rum. I stedet bruger jeg hellenismebegrebet som betegnelse for en mediterran fælleskultur, om hvilken det gælder, hvad Marshall Sahlins $(1999,412)$ har hævdet om kultur generelt, at den er "always foreign in origin, but distinctively local in pattern." Det er i den sammenhæng, jeg nu vender tilbage til spørgsmålet om kætterkonstruktionen som del af et bredere fænomen i hellenistisk tid og mere snævert i det udsnit af epoken, hvor også den tidlige Kristusbevægelse vokser frem.

Rebecca Lyman har overbevisende argumenteret for, at det kristne hæresibegreb dårligt kan forstås uafhængigt af den romersk-imperiale kontekst, i hvilken det blev til. I et blandt flere vigtige essays om dette emne skriver hun (2003a, 215):

The historical development of a particular discourse of religious exclusivity should then be read in the continuum of common contemporary problems of identity, hybridity, and authority in the second century, even if authors of Christian identification are often more extreme in scale.

12 Mereologien er den del af videnskabsteorien, som fokuserer på forholdet mellem del og helhed, ligesom den også berører spørgsmålet om relationen mellem enkeltdelene inden for helheden. 
I samme essay pointerer hun også, hvordan man i lyset af indsigter fra postkoloniale teorier netop kan nå frem til en forståelse af:

the "invention of heresy" in the second century as an intellectual creation by particular individuals in response to issues of social identity and philosophical meaning within Roman Hellenism itself, rather than as a cultural translation of an essential Christian exclusivity (ibid., 211).

Hvis dette projekt imidlertid skal have mening, må man kunne pege på sådanne eksempler. Jeg mener, der er to helt oplagte områder at fremdrage, nemlig de medicinske traditioner og de filosofiske; men her vil jeg nøjes med at tage et kort, afsluttende udblik til de filosofiske traditioner, der var samtidige med hæresiologerne. Netop Justin fremdrog i skildringen af sin vej ind i Kristusbevægelsen i skriftet Dialog med jøden Tryfon først de filosofiske retninger siden jødedom som en analogi til Kristusgruppen, og som dem han først havde frekventeret, inden han fandt sandheden i kristendommen. Det er næppe tilfældigt, at Justin så en sammenhæng, skønt han selv var ivrig efter at underbetone den, mellem kristendom og filosofi (se hertil Lyman 2003b; Petersen 2013b).

I en tankevækkende artikel om eklekticisme hos middel-platonikerne og nypythagoræerne stillede John Dillon $(1988,103)$ spørgsmålet om ortodoksi og heterodoksi eller kætteri i platonismen i forlængelse af Akademiets forsvinden i 88 f.v.t. Interessant i vores sammenhæng er Antiokus af Askalon (130-68 f.v.t.), som ikke alene er kendt som afgørende inspirationskilde for Cicero, men også som stifteren af det, vi i dag betegner middel-platonismen (Dillon 1996, 52-113). Når Antiokus er betydningsfuld i denne kontekst, hænger det sammen med, at han plæderede for en tilbagevenden til Det Gamle Akademi, altså et opgør med nutiden, ikke mindst vendt mod Filon af Larissa, i en plaidoyer for en besindelse på fortidens rene lære, altså som en tanke om ortodoksi (Dillon 1988, 105). I sin artikel giver Dillon også andre eksempler fra en græsk-romersk filosofisk sammenhæng, der - uden at han i øvrigt går ind på denne problemstilling - understreger den pointe, at de kristnes brug af kætterbegrebet nok var, som Lyman (2003a, 215) har formuleret det, "more extreme in scale", men netop ikke en eksklusiv kristen foreteelse. Og dermed er jeg nået vejs ende.

\section{Kætteri som kristen prægning eller utopisk religionsfænomen - en afslutning}

Der har igennem mange år været en fuldt forståelig tradition for at argumentere for kætterbegrebets fremkomst hos de kristne hæresiologer. Det giver god mening, hvis man ser på den specifikke 'kætterske' anvendelse af det græske begreb hairesis og det beslægtede latinske ord secta, som i den særlige brug er specifik for de kristne hæresiologer. Ikke desto mindre har jeg her argumenteret for, at de kultur-, religions- og 
socialhistoriske forudsætninger for det kristne kætterbegreb skal findes i fremkomsten af det fænomen, man ofte betegner aksetid. Jeg har yderligere plæderet for, at kætterbegrebet skal ses i snæver sammenhæng med overgangen fra lokativiske til utopiske religionsformer, som også er en betydningsfuld del af aksetidsproblematikken. Det er karakteristisk for de sidste, at de trives dårligt med eksistensen af parallelle fordringer på én sandhed, fordi de netop abonnerer på samme himmelske verden, uanset om de reduplicerer himlen i tre, ni, eller tretten himle, etc., for alle er de forskellige manifestationer af den ene og samme guddommelige himmel. Kunne de i denne verden - som i lokativiske religioner - nøjes med deres stedlige tempel, ville problemet ikke være så stort, eftersom arkaiske religioner uproblematisk lever med en mangfoldighed af templer, i hvilke forskellige guder eller aspekter af en og samme gud indeksikalt tænkes at være til stede. Men projicerer man sin verdensfordring og længsel op på den himmelske hvælving og hævder, at just dér har man sin egentlige bolig, er der ikke plads til både en selv og de andre, som gør krav på samme celestiale habitat. Dertil kommer, at utopiske religioner, fremhjulpet af øget social kompleksitet med stigende autonomisering af forskellige sociale klasser, tilblivelsen af en egentlig skriftkultur med udviklingen af kanoniske skriftsamlinger, en profileret form for globalisering, etc., må vogte sig for doktrinær udglidning. Er sandheden, ideologisk set, monolitisk, kan man principielt ikke have et alt for bredt variabilitetsspektrum af sandheder. Der er kun plads til den ene; men det er selvsagt set fra det ideologiske perspektiv, for historisk, i den sociale og institutionelle virkelighed, forholder det sig anderledes. Der er netop mange, som alle gør krav på sandheden, både inden for og uden for bevægelsen. Kætteri eller hæresi er i den sammenhæng et institutionelt værn mod eksistensen af de mange sandheder inden for bevægelsen.

Når det gælder kultur- og socialhistoriske forudsætninger for den kristne prægning af kætterbegrebet, har jeg henvist til de græsk-romerske filosofiske og medicinske traditioner, hvor vi også finder eksistensen af forskellige skoler og retninger, som internt bekæmper hinanden. Jeg har med inspiration hos Lyman argumenteret for, at forestillingen om en kristen eksklusiv konstruktion af kætterkategorien af flere grunde er problematisk. Dels geråder den i problemer i forhold til en mere principiel kulturteoretisk stillingtagen til det mereologiske problem om, hvordan forholdet mellem kulturel enkeltdel og helhed skal konciperes. Dels geråder den i vanskeligheder i relation til den mere specifikke historiske problemstilling, eftersom der i den periode og i det rum, hvor det kristne hæresibegreb prægedes, de facto fandtes en række paralleller. Dertil kommer, at det ville være vanskeligt at forstå rationalet for hæresiologernes sammenstillinger af de filosofiske bevægelser med Kristusbevægelsen i relation til kætterspørgsmål, hvis ikke der i den historiske kontekst var et tertium comparationis.

Afslutningsvis hævder jeg, at kætterbegrebet forudsætter en kontekst, hvor forskellige, men beslægtede retninger inden for samme overordnede bevægelse gør krav på samme diskursive rum med en simultan afskrivning af rivaliserende strømninger som mangelfulde, fejlagtige og ufuldkomne. Ortodoksi udspringer i den sammenhæng af en institutionel, retorisk positionering, som lukker den historiske situations åbenhed 
gennem forsøget på semiotisk fastfrysning af en bestemt tegnkrystallisering (inkl. social/rituel praksis) med en tilsvarende udsondring af rivaliserende tegnfortolkninger (inkl. social/rituel praksis). Hvis det jeg her tentativt har argumenteret for, er plausibelt, er det afgørende, at andre følger op på det. Argumentationen er alene troværdig, hvis det også er muligt at dokumentere, at samme forhold gør sig gældende i oldtidens Kina i forbindelse med konfuzianismens fremkomst; at vi finder beslægtede fænomener i overgangen fra vedisk til upanishadereligiøsitet i oldtidens Indien og i fremkomsten af nye religiøse bevægelser som fx jainisme og buddhisme; at paralleller kan iagttages i det antikke nærorientalske område, også uden for det israelitiske.

\section{LITTERATUR}

Arnal, William E.

2008 "Doxa, Heresy, and Self-Construction: The Pauline Ekklēsiai and the Boundaries of Urban Identities", in: Eduard Iricinschi og Holger M. Zellentin, eds., Heresy and Identity in Late Antiquity, Mohr-Siebeck, Tübingen, 50-101.

Ayres, Lewis,

2006 "The Question of Orthodoxy", Journal of Early Christian Studies 14 (4), 395-398.

Bauer, Walter,

1934 Rechtgläubigkeit und Ketzerei im ältesten Christentum, Mohr-Siebeck, Tübingen.

Bellah, Robert N.

2005 "What Is Axial about the Axial Age?", European Journal of Sociology 46 (1), 69-89.

2011 Religion in Human Evolution. From the Paleolithic to the Axial Age, Belknap Press of Harvard UP, London \& Cambridge, MS.

Berlinerblau, Jacques

2001 "Toward a Sociology of Heresy, Orthodoxy, and Doxa", History of Religions 40 (4) 327-351.

Boulluec, Alain le

1985 La notion d'hérésie dans la littérature grecque II -IIIe siècles. Tome I. De Justin à Irénée, Études Augustiennes, Paris.

Boyarin, Daniel

2004 Border Lines. The Partition of Judaeo-Christianity, University of Pennsylvania Press, Philadelphia.

Burrus, Virginia

1995 The Making of a Heretic: Gender, Authority and the Priscillianist Controversy, University of California Press, Berkeley.

Davidsen, Markus

2010 "Fiktionsbaseret religion: Fra Star Wars til jediisme", Religionsvidenskabeligt Tidsskrift 55, 3-21.

Dehandschutter, Boudewijn

2011 "Heresy and the Early Christian Notion of Tradition", in: Joseph Verheyden og Herman Teule, eds., Heretics and Heresies in the Ancient Church and in Eastern Christianity, Peeters, Leuven, Paris, Walpole, MA, 7-21

Dillon, John M.

1996 The Middle Platonists 80 B.C. to A.D. 220, Cornell UP, New York.

1988 "'Orthodoxy' and 'Eclecticism': Middle-Platonists and Neo-Pythagoreans" in: John M. Dillon \& A.A. Long, eds., The Question of "Eclecticism": Studies in Later Greek Philosophy, University of California Press, Berkeley. 
Glucker, John

1978 Antiochus and the Late Academy, Vandenhoeck \& Ruprecht, Göttingen.

Harrington, Daniel J.

1980 "The Reception of Walter Bauer's “Orthodoxy and Heresy in Earliest Christianity" During the Last Decade", Harvard Theological Review 73 (1-2), 289-298.

King, Karen L.

2008 "Social and Theological Effects of Heresiological Discourse", in: Eduard Iricinschi og Holger M.

Zellentin, eds., Heresy and Identity in Late Antiquity, Mohr-Siebeck, Tübingen, 28-49.

Leff, Gordon

1967 Heresy in the Later Middle Ages: The Relation of Heterodoxy to Dissent, c. 1250-1450, vol. 1, Manchester UP, Manchester.

Locke, John

1963 A letter concerning toleration / Latin and English texts rev. and ed. with variants and an introduction by Mario Montuori, Martinus Nijhoff, Haag.

Lyman, Rebecca,

2003a "Hellenism and Heresy", Journal of Early Christian Studies 11 (2), 209-222.

2003b "The Politics of Passing. Justin Martyr's Conversion as a Problem of "Hellenization"”, in: Kenneth Mills \& Anthony Grafton, eds., Conversion in Late Antique and the Early Middle Ages: Seeing and Believing, University of Rochester Press, Rochester, NY, 36-60.

Petersen, Anders Klostergaard

2003 "Leve kætteren", Kritisk Forum for Praktisk Teologi 94, 2-12.

2009a "Constraining Semiotic Riverrun. Different Gradations and Understandings of Canonicity and Authorative Writings", in: Anders-Christian Jacobsen, ed., Religion and Normativity. The Discursive Fight over Religious Texts in Antiquity, Aarhus UP, Aarhus, 22-41.

2009b "Reconstructing Past (Jewish) Cultures", in: Károly Dániel Dobos og Miklós Köszeghy, eds., With Wisdom as a Robe. Qumran and Other Jewish Studies in Honour of Ida Fröhlich, Sheffield Phoenix Press, Sheffield, 367-383.

2011 "Rituals of Purification, Rituals of Initiation. Phenomenological, Taxonomical and Culturally Evolutionary Reflections", in: David Hellholm, Øyvind Nordeval, \& Christer Hellholm, eds., Ablution, Initiation, and Baptism. Late Antiquity, Early Judaism, and Early Christianity, vol. 1-3, Berlin og New York, De Gruyter, vol. 1, 3-40.

2012a "“Invention" and "Maintenance" of Religious Traditions: Theoretical and Historical Perspectives", in: Jörg Ulrich, Anders-Christian Jacobsen \& David Brakke, eds., Invention, Rewriting, Usurpation. Discursive Fights over Religious Traditions in Antiquity, Peter Lang, Frankfurt, 129-160.

2012b "Othering in Paul: A Case-Study of 2 Corinthians", in: Maijastina Kahlos, ed., The Faces of the Other. Religious Rivalry and Ethnic Encountes in the Later Roman World, Brepols, Turnhout, 19-50.

2012c "Konstruktionen von Geschlecht und Sexualität im Neuen Testament", Zeitschrift für Neues Testament 30 (15), 12-23.

2013a “Attaining Divine Perfection through Different Forms of Imitation", Numen 60 (1), 7-38.

$2013 b$ "Justin Martyr in Search of the Self", in: Gregory Woolf \& Jörg Rüpke, eds., Religious Selves in the Second Century, Mohr-Siebeck, Tübingen, under udgivelse.

Sahlins, Marshall

1999 "Two or Three Things That I Know about Culture", The Journal of the Royal Anthropological Institute Incorporating Man 5 (3), 391-421.

Simon, Marcel

1979 "From Greek Hairesis to Christian Heresy", in: William R. Schoedel \& Robert L. Wilken, eds., Early Christian Literature and the Classical Intellectual Tradition in Honorem Robert M. Grant, Éditions Beauchesne, Paris.

Smith, Jonathan Z.

1978 Map Is not Territory. Studies in the History of Religions, Brill, Leiden.

1990 Drudgery Divine. On the Comparison of Early Christianities and the Religions of Late Antiquity, Chicago UP, Chicago. 
Staden, Heinrich von

1982 "Hairesis and Heresy: The Case of the haireseis iatrikai", in: Ben F. Meyer \& Ed P. Sanders, eds., Jewish and Christian Self-Definition, vol. 3, Self-Definition in the Graeco-Roman World, Fortress Press, Philadelphia, 76-100.

Thomassen, Einar

2012 “What Is Heresy, and Why Did it Matter?", in: Jörg Ulrich, Anders-Christian Jacobsen \& David Brakke, eds., Invention, Rewriting, Usurpation. Discursive Fights over Religious Traditions in Antiquity, Peter Lang, Frankfurt, 191-201.

Völker, Walther

2006 "Walter Bauer's Rechtsgläubigkeit und Ketzerei im ältesten Christentum", reviewed by Walther Völker. Translated from German by Thomas P. Scheck, Journal of Early Christian Studies 14 (4), 399 405 [oprindeligt 1935].

Zito, George V.

1983 "Toward a Sociology of Heresy", Sociological Analysis 44 (2), 123-130.

\section{INTERNETSIDER:}

"Cathecismus catholicae ecclesiae"

http://www.vatican.va/archive/catechism_lt/index_lt.htm (set 18.10.2012).

Anders Klostergaard Petersen, professor MSO, cand.theol. Religionsvidenskab, Institut for Kultur og Samfund Aarhus Universitet 